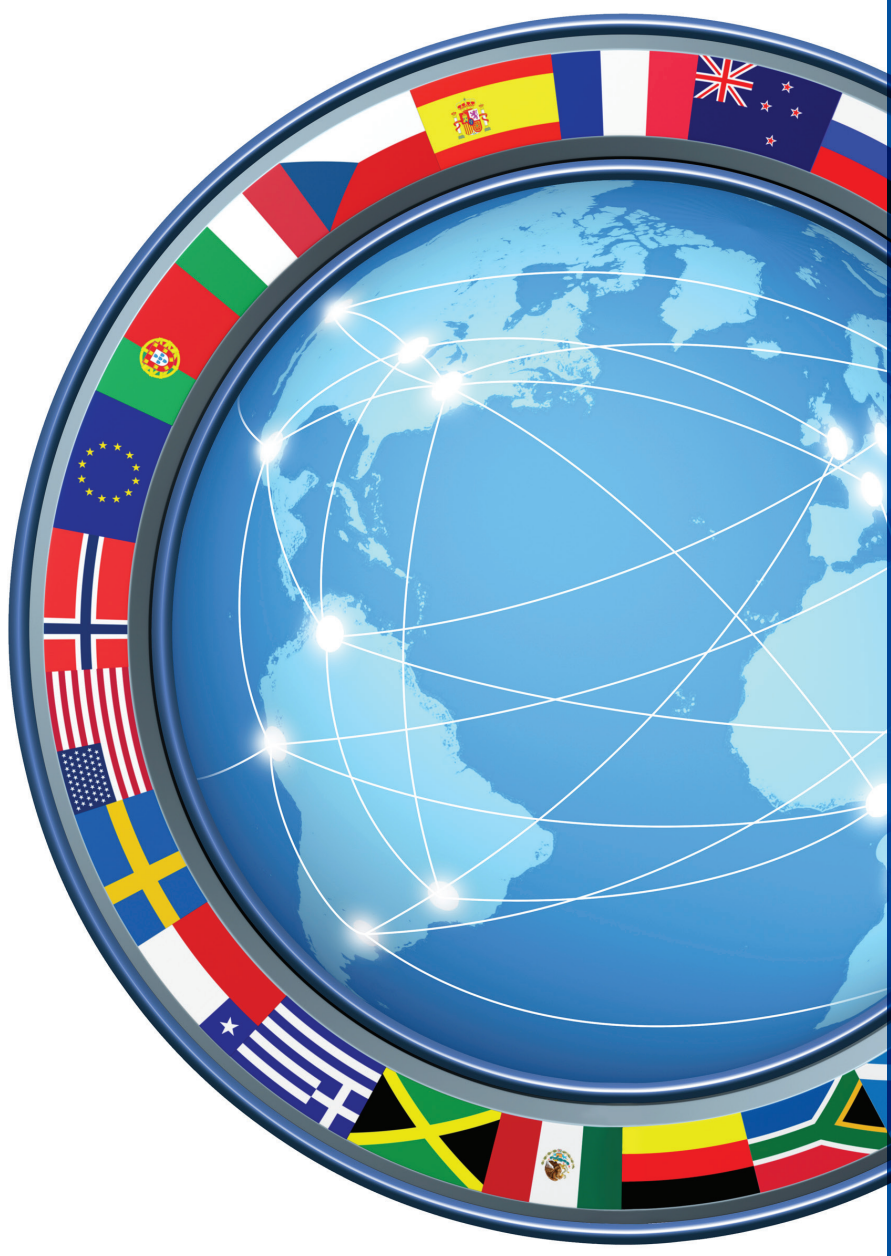

\title{
PRACTICAL ASPECTS
} IN DOING INTERNATIONAL BUSINESS

\section{editors}

Tomasz Dorożyński Janusz Świerkocki 


\section{Chapter 4}

\section{International business transactions}

Bogdan Buczkowski

\subsection{Foreign market entry modes}

In today's global economy, international business offers better development opportunities and greater possibilities to make profits to enterprises than business activities run solely on the domestic market, although at the same time enterprises take greater risks related to running their business activities.

From the point of view of the degree of involving the company's resources, the modes of expansion can be divided into the following groups:

1. Foreign trade;

2. Non-capital co-operation forms;

3. Capital cooperation forms.

Alongside their growing experience, companies gradually progress from the forms that require less involvement of their resources to more advanced forms (Figure 4.1).

The success of an enterprise starting its internationalisation process depends largely on the accuracy of decisions made as to the choice of the mode of entry into foreign markets, forms of business organisation, capability of maintaining comparative advantages, but also on the maturity of international organisational structures. The choice of the mode of entry into a foreign market is a decisive factor affecting the future functioning of a business, the degree of its independence and the amount of capital involved 


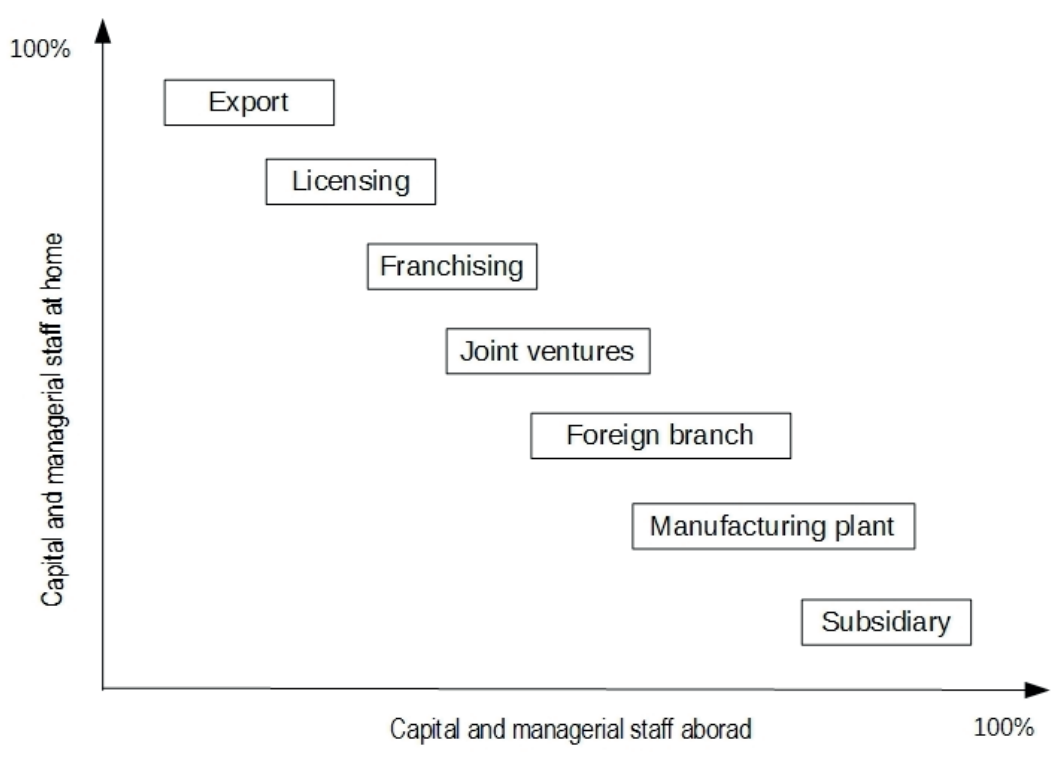

Figure 4.1. Phases of the internationalisation process of a firm Source: Author's study based on http://www.exporter.pl

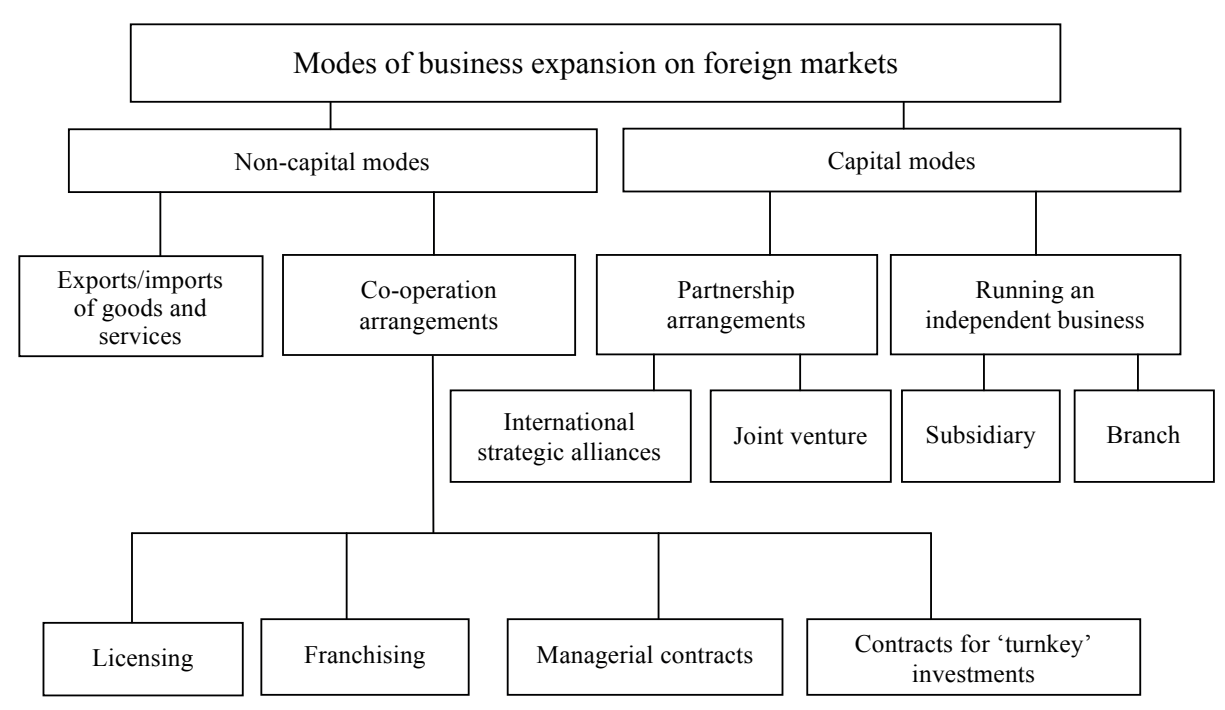

Figure 4.2. Modes of international business expansion

Source: Author's study based on: Gorynia, 2000, p. 52 
Modes of business expansion can be also divided into four groups (Figure 4.2):

1. Imports/exports of goods and services;

2. Cooperation arrangements - licensing, franchising, managerial contracts, contracts for 'turnkey' investments;

3. Partnership agreements in the form of strategic alliances or joint ventures;

4. Running an independent business by foreign direct investment - establishment of subsidiaries or branches.

\subsubsection{Non-capital forms of operating on the international market}

The basic forms of international trade are: import, export and transit commerce, but there are also some specific forms such as counter trade or inward and outward processing and repair transactions. One shared feature of these forms of trade is that they take place on the free market and directly between producers and recipients or by specialised foreign trade companies acting as intermediaries. Part of the transactions are concluded at organised markets, such as fairs, stock markets, auctions, tenders or customs free areas.

Indirect export, which usually constitutes the first phase of a company's foreign expansion, consists in the sales of goods abroad from the country of the exporter via independent intermediaries (Table 4.1). The cooperation between the producer and the export intermediary usually takes two forms:

1. The producer selects a foreign trading company and orders the sale of his/her goods on a foreign market, granting to the trading company the exclusive right to sell,

2. The trading company uses the current offer of the producer.

Commercial intermediaries differ from one another, depending on the type of risk they take. According to this criterion we can distinguish the intermediaries operating:

- for the account and in the name of the principal (exclusive or nonexclusive agent, del credere agent, general agent), CIF-agent, trade broker; 
- for the account of the principal and in his/her own name: commission agent, consignee;

- for his/her own account and in his/her own name: distributor, merchant (dealer) who, by taking on the full costs and risk of export operations, benefits in full from the profits made, although he/she is also exposed to any potential loss.

Direct export is most often involved in the case of trading in investment goods as well as in highly individualised goods, produced under specialised contracts, where all elements of a transaction need to be agreed with the foreign recipient.

Direct export operations can be handled by (Table 4.1):

- home offices or exports department,

- foreign sales departments or subsidiaries,

- commercial travellers,

- foreign agents or distributors,

- the Internet.

Table 4.1. Types and role of intermediaries in direct and indirect export

\begin{tabular}{|l|l|}
\hline \multicolumn{2}{|c|}{ Indirect export } \\
\hline Export house & $\begin{array}{l}\text { Purchases the goods from other companies and sells } \\
\text { them abroad for his own account. }\end{array}$ \\
\hline $\begin{array}{l}\text { Intermediary of the foreign } \\
\text { buyer (confirming house) }\end{array}$ & $\begin{array}{l}\text { Acts on the request of a foreign buyer, who remits } \\
\text { an appropriate margin for the purchasing services; } \\
\text { the intermediary guarantees to the seller the payment at } \\
\text { the moment of the delivery of goods. }\end{array}$ \\
\hline Buying houses & $\begin{array}{l}\text { Act on behalf of the client, often a foreign department } \\
\text { store, for whom the purchase from local producers is } \\
\text { made. }\end{array}$ \\
\hline Piggybacking & $\begin{array}{l}\text { Sales of goods with the use of the distribution network of } \\
\text { another, usually large, company. }\end{array}$ \\
\hline
\end{tabular}




\begin{tabular}{|l|l|}
\hline \multicolumn{2}{|c|}{ Direct export } \\
\hline Agent & $\begin{array}{l}\text { Sells in the name and for the account of the exporter, } \\
\text { receiving an appropriate margin in return for the services; } \\
\text { an agent may sell the goods of one or more, sometimes } \\
\text { rival, companies. }\end{array}$ \\
\hline Distributor & $\begin{array}{l}\text { Sells in his/her own name and his/her income draws from } \\
\text { the difference between the purchase and the sales price } \\
\text { of given merchandise. }\end{array}$ \\
\hline Direct sales & $\begin{array}{l}\text { Sales representatives (salespersons) acting on both } \\
\text { domestic and foreign markets }\end{array}$ \\
\hline Trade representation & $\begin{array}{l}\text { An organisation employs its own or local personnel to } \\
\text { operate on a foreign market. }\end{array}$ \\
\hline
\end{tabular}

Source: Author's study based on Fonfara, Ciesielski, 1999, p. 14.

Co-operative exporting is among the indirect forms of export in which the exporter co-operates with one or more domestic or foreign companies since he/she cannot operate on the foreign markets on his/ her own, due to a lack of sufficient capital and staff or appropriate competences. In order to achieve common goals through export activities, the co-operating companies pool together their resources and share both the risk and the cost of joint operations. The co-operation of producers-exporters may take the form of a group of exporters or piggy-backing - an arrangement in which usually a big company allows a small one to use its distribution network to sell products/services that are complementary to its own products (or at least do not compete with them) and appeal to the same customers. The small firm, benefiting from the extensive sales network and brand image of the larger company, exports its products/services at lower risk and lower costs, including logistics and administration. The big firm, thanks to this cooperation, enriches the range and scale of its sales, as well as quickly recovers a part of the capital invested in the creation of the distribution network. Sometimes a big firm also uses the distribution network of a small one.

A characteristic feature of transit trade is the fact that it does not take place directly between the exporter, from the country where the goods originate, and the importer, based in the destination country, but via a transit company based in a third country. Such trade may result from compensation transactions, or producers' and/or recipients' poor 
knowledge of foreign markets. The reasons may also be trade protectionism or political motivations. Transit trade may take either direct or indirect forms, also called direct or indirect re-export.

The use of counter trade may result from payment difficulties between parties to foreign trade transactions and can take the form of barter, compensation buying, buy-back or offset. In barter transactions, no money is used, since the transaction essentially concerns the exchange of goods in kind-goods are simply exchanged for other goods of the same value.

In the case of compensation transactions, exporters undertake commitments to buy certain goods or services from importers. There are two transactions, not necessarily equivalent, implemented and financed individually, and the time of their execution can be relatively long.

Buy-back transactions are most often found in the exchange of investment goods. The exporter undertakes to buy from the importer the goods produced with the use of machines, equipment or other investment goods that the exporter previously delivered.

Among offset transactions we find high value long-term transactions (lasting even as long as 30 years). They differ as to the role of the state in the process of implementing trading arrangements and the degree of the functional link between the compensation goods and the goods delivered within the main (primary) export transaction. Whereas in buy-back transactions, the delivery of machines and equipment is paid back with the goods produced with the use of this equipment, in the case of offset arrangements, the compensation goods or services quite often go beyond the scope of the primary export transaction (indirect offset). Most often, the exporter undertakes to put into operation in the importer's country the licensed production of certain goods, or to purchase (or find a buyer for) certain goods designated by the importer, or to contribute shares in a selected company or to conclude a subcontracting arrangement with a designated economic entity in the importer's country.

A close connection between compensation goods and services and the exported product characterises direct offset, usually found in the military, construction and energy sectors. Conversely, in indirect offset, the commitments and liabilities do not have a direct association with the export project implemented: they involve rather the activities aimed at improving the economic situation of the country purchasing the technologically advanced goods. Offset transactions usually involve 
concluding several contracts. Next to the main export contract (for armament, aircrafts, power units), the essential offset (compensation) contract between the government and the exporter is concluded. The compensation contract stipulates the scope and value of the offsetting activities to be implemented in the importer country's territory or in the territory of other countries, together with entrepreneurs from the importer's country. Both contracts are usually concluded at the same time.

Licence sale is a form of entry into a foreign market in which the right to profit-making exploitation of intangible assets, which are subject to patent or industrial designs protection, is granted to the buyer in return for a one-time or continuous licence fee (royalties). Assets traded under licence sales are technical, organisational or technological solutions, models and designs, brands, trademarks or know-how (which is also an intangible industrial asset, however, one which does not fall under patent or registration protection). When it comes to liabilities on the side of the licensor, we can distinguish between pure (patent) and mixed (complex) licensing transactions. As far as the scope of rights granted is concerned, we can name full or partial transactions as well as exclusive and non-exclusive ones (including full exclusive and non-exclusive partial ones).

Franchising, which is a wider form of internationalisation than mere licensing and as such covers all type of licensing relationships, usually takes the form of product and trade name franchising as well as business format package franchising. While under licensing transactions only some elements of the business (brand, trade mark, industrial design or technology) are the subject of the transaction, in franchising agreements (in particular in package franchising) the franchiser grants to the franchisee - in return for financial remuneration - the right to use the complex business operation model. Contract of that kind are found mainly in the services and trade sectors.

The essence of contract manufacturing abroad consists in concluding with a local producer an agreement for manufacturing and servicing of products (according to the specifications provided), with the right to decide about sales, pricing, distribution and marketing left in the hands of the principal.

Subcontracting and original equipment manufacturing contracts are among the export-import type of transactions, since they consist in providing the contractor with components for the manufacturing of final goods intended for sales on a given market. 
Managerial contracts constitute a form of international activities of enterprises consisting in the provision of company management services by a team of appropriately knowledgeable and experienced personnel. This managerial team, however, cannot undertake any commitments or make key decisions related to the company managed without prior permission of the principal.

Turnkey investment contracts (concerning complex investments) constitute a specialised category of managerial contracts and at the same time they are among the most advanced, complicated and risk-charged non-capital forms of internationalisation.

\subsubsection{Forms of operating on the international market with capital involvement}

A joint venture is a capital form of operation on a foreign market, which consists in establishing a company with the participation of an independent foreign partner. The shareholders bring into the company contributions in kind, financial resources, know-how or knowledge of local markets and the domestic regulations in force. The contributions of foreign partners are usually: capital, brand and technology, while local partners usually bring in: local staff, land, local contacts, distribution networks and other resources. Thus, the resources of both parties are involved and the risk and rewards involved in a joint enterprise are shared. The chances of success are larger when the shares and contributions of both partners are similar and where there are no substantive differences in opinions, systems of values and the methods of operation.

From the point of view of the size of partner share, joint ventures may be divided into majority, minority and parity joint ventures. In turn, as far as the market sectors are concerned, we can distinguish commercial, manufacturing or service joint ventures, while the roles the partners play in the production and distribution chain determines the division of joint ventures between vertical ones (enterprises belong to different levels) or horizontal ones (the partners are from the same level). Joint ventures can be formed for indefinite or definite periods of time, i.e. for the execution of a particular project only.

Strategic alliances are voluntary business cooperative agreements, concluded between both competing and non-rivalling companies. Among the alliances of non-rivalling enterprises, we find vertical partnerships, established by companies from different levels of the distribution 
channel, which operate on the basis of the provider-recipient relationship. Intersectoral agreements are concluded between the companies involved in entirely different activities with no provider-recipient relationship between them. Multinational joint ventures are such forms of cooperation in which one of the partners disposes of an attractive product while the other one offers access to the desired markets.

The alliances formed by competing companies include:

- complementary alliances, whereby co-operation takes place between the producers of goods intended for similar use and it aims at a more efficient exploitation of the functions these goods already possess,

- integrating alliances, formed for the joint production of some elements that are later used separately by each of the partners,

- additive alliances, which consist in co-operation aimed at the joint manufacturing of a single product, in consequence leading to the suspension of competition between the partners.

Among the strategic alliances we can also distinguish manufacturing, distribution, research and development alliances or consortia, which are close in nature to joint ventures.

Foreign direct investments (FDI) constitute a form of running independent operations abroad, which consists in establishing subsidiaries or branches and represent the most capital-intensive and risk-charged mode of entry into a foreign market. They can be created either by the purchase (take-over) of an already existing company operating in a given sector (brownfield investment), or by establishing a new company (greenfield investments). A new entity can be a direct branch, a wholly-owned subsidiary or a joint venture. The basic difference between a branch and a foreign subsidiary is that a branch is subject to the law of the country of origin and constitutes an integral part of the mother company, which bears the full responsibility for branch operations. A subsidiary, in turn, has its own legal personality and is a separate unit, operating under the law of the host country.

Companies usually undertake various measures to reduce the risk of international business transactions. Appropriately formulated agreements and contracts constitute the principal and most commonly used tool for minimising these risks. 


\subsection{Preparation and conclusion of commercial transactions}

\subsubsection{Inquiries, offers, orders and contracts}

An entrepreneur who intends to find a contractor formulates an inquiry, usually in the form of a commercial letter, and sends it out by post, fax, e-mail, or sometimes even via SMS or MMS, to selected companies. The purpose of the inquiry, which does not involve any legal consequences for the parties, is inviting the addressee to submit an offer to sell given goods or services.

An offer (also a bid or tender) is a binding proposal to purchase/ sell merchandise or to provide services (or both), which specifies explicitly the definite terms of the future sales/purchase contract. Submitting a non-binding offer is also possible, but its non-binding nature must be clearly stated in the document. An offer submitted following an inquiry is a solicited offer or bid, while an offer sent on the initiative of the seller, without prior inquiry, constitutes an unsolicited offer/bid.

The acceptance of the offer by the offeree should be full and unconditional as only such an acceptance is binding for the bidder. This acceptance can take the form of placing an order, by which the sender gives his/her approval to conclude the export/import contract, under conditions previously agreed with the partner. The acceptance of the offer without reservations, e.g. in the form of an order confirmation, means that a contract has been concluded. The contract can also be concluded by further specification of the offer as a result of negotiations with subsequent confirmation of this clarified offer by the seller, or in the form of a single legal document. Such a single legal document, or a single document contract, containing all provisions regarding mutual considerations by the parties, may take the form of a standard contract, prepared with the use of a special form/template. However, in foreign trade, multi-document contracts are used more often. They result from the exchange of documents (inquiry, offer, acceptance of offer, order placement, order confirmation) between the parties.

Regardless of the way in which a contract is concluded, it should contain certain key elements, known as standard clauses, referring to the contractual obligations such as: subject of the contract, the amount of goods or scope of services, pricing, the place of goods or services delivery, delivery terms according to appropriate trading rules (e.g. Incoterms, 
Combiterms, RAFTD), the date of delivery, means of transportation and payment terms. The contract may also list additional clauses/conditions: e.g. the jurisdiction clause, arbitration clause, revision clause, price review clause, entry into force clause, force majeure clause, re-export prohibition clause, liquidated damages clause or complaint clause. These supplementary conditions can be formulated by one of the parties or recommended by professional organisations, chambers of commerce as well as state or international authorities. The inherent parts of the contract are also appendices of various kinds, including: description of technical conditions, specifications, instructions concerning packaging, labelling or loading, etc.

\subsubsection{Law applicable to the contract}

By law applicable to the contract we mean the law which governs the contractual arrangements between the parties and to which the parties and courts refer in case of disputes arising under the contract. The choice of the applicable law exerts its influence on a number of key elements of the contract, both at the stage of the contract's formulation and during the implementation phase.

Legislations of the majority of states and international conventions guarantee to the contracting parties a fundamental right of the freedom of contract (concluded in good faith and according to the rule of business honesty). The freedom of contract refers to the autonomy in shaping the substantive contents of an agreement, choice of its form (written, oral, electronic, expressed with gesture), language and the law governing the contract. The contractual provisions cannot, however, contravene, under pain of invalidity, public law provisions (fiscal, monetary or related to sanitary norms), and those norms of domestic, international and supranational laws in force which are applicable according to the appropriate provisions of private international law (national laws regulating foreign exchange and applicable by virtue of relevant conflictof-laws rules of private international law).

The legal capacity of the parties to conclude a contract is determined according to the national law of the country of residence (natural persons) or of the seat of a company. The form of the contract is assessed according to the conflict-of-law rules and usually it is the law of the country where the contract is concluded. 
An international contract is thus governed by the law explicitly chosen by the parties, for instance, in the law of the contract clause. The selection of the applicable law can also be implicit, yet still must unambiguously result from the provisions of the contract or from the wider context of a given case. The applicable law may be that of the country of one of the parties to the agreement, or the law of a third country. The parties can also choose international commercial law, resulting from international agreements to which one of the countries country is a party. Resolutions by international organisations or systems of sectoral commercial practices and usage, formulated and published by governmental and professional organisations, may also govern the contractual relations between the parties. These customary commercial practices usually overlap with the legal systems of the signatory countries. Among these arrangements we find: UNIDROIT Principles of International Commercial Contracts, the United Nations Convention on Contracts for the International Sale of Goods (UN CISG), The Principles of European Contract Law (PECL) and Regulation (EC) No 593/2008 of the European Parliament and of the Council of 17 June 2008 on the law applicable to contractual obligations (Rome I), replacing the Rome Convention on the Law Applicable to Contractual Obligations.

The parties may choose the applicable law for the entire contract or part of it, for example with the use of the following provision: 'The contract shall be governed by Polish law, with the exception of Article ..., subject to Spanish law' or 'The Contract shall be regulated by UN CISG, except for Art. ...., which, should such a need arise, may be amended in accordance with German law.' The choice of the law applicable does not exclude later changes in this respect, related to both the entire contract and to any part of it.

In the case of parties not having chosen the law of the contract, or when the choice made is ineffective, the determination of the governing law belongs to the authority competent to settle the dispute, according to the rules of private international law (conflict-of-law rules) of the country in which this authority is based ${ }^{1}$.

1 In practice, it is usually the country of residence of the defendant or, in the case of an enterprise, the country where the company is registered, conducts its business activities and where its office and its property are based. This is because it is easier to force the defendant to appear before the court than in the case when he/she remains outside this court's jurisdiction. 
The law of the country of the seller will be the applicable law, because it is most closely connected with the contract concluded ${ }^{2}$. The law of the country where the dispute takes place, where the contract has been concluded and is implemented, or where the immovable property is located, may be also chosen as the governing law. It can also be the law of the country of the language in which the contract was concluded, whose currency is used in invoicing or payments, or even the law of the country whose flag is flown on the vessel carrying the goods.

The aforementioned conventions and international agreements, providing for the standardisation of laws relating to commercials transaction on international markets, serve the purpose of eliminating the necessity to consider various factors, when decisions as to the applicable laws are taken. International conventions or private international law should apply when decisions as to the choice of the law governing the contracts are taken in the case of contracts concluded with contractors from outside the EU.

Regulation (EC) No 593/2008 of the European Parliament and of the Council of 17 June 2008 on the law applicable to contractual obligations (known as the Rome I Regulation), provides for the rules applicable to the choice of the law governing contracts concluded between EU contractors. The Regulation is directly applicable in the EU territory and takes precedence over international conventions and domestic laws. Although the principal rule is the freedom of choice of the law applicable, the parties' autonomy is limited to the choice between the laws of designated

2 In the case when no choice of EU contracting parties has been made according to the 'Rome I' Regulation, the contract should be governed by the law of the country where the party required to effect the characteristic performance of the contract has his habitual residence. A characteristic performance is such a performance, usually non-pecuniary, which decides the specificity of the contract in question. In the case of a sales contract, the performance is that of the seller, and the contract will be governed by the law of the country in which the seller has the place of habitual residence - the place where the main office is based (Article 19). Similar rules for the designation of the law governing the contract are applied in the case of services contracts as well as those related to distribution, credits or franchising. Different rules apply to contracts relating to rights in rem in immovable property or tenancies of such property. These contracts are governed by the law of the country where the property is situated. The 'Rome I' Regulation also provides for specific arrangements concerning specific types of contracts such as: contracts concerning carriage, insurance, voluntary assignment of receivables, individual employment contracts or contracts concluded with consumers. In those cases, regardless of the choice made by the parties, some specific limitations deriving directly from the Regulation apply. 
countries, which excludes the possibility of preference being given to the law contained in private codifications: UNIDROIT, Principles of International Commercial Contracts or Principles of European Contract Law.

In short, each contract is subject to its governing law, chosen by the parties to the agreement or - in the absence of the governing law clause in the contract or in the case of ineffectual choice - to the law specified by private international law regulations. International agreements ratified by a given country, constituting an integral part of any domestic legal system, take precedence over the rules established by national laws.

\subsubsection{Commercial jurisdiction and enforcement of judgements}

When a dispute under an international sales contract arises, it is important to identify the proper jurisdiction, i.e. the court competent to hear the case. The generally accepted rule provides that judgements given by courts in one country are binding in the territory of this country, while the recognition and enforcement of judgement by courts of other countries depends on whether a national law (bill) or international agreements provide for such a possibility.

The New York Convention of 1958 on the Recognition and Enforcement of Foreign Arbitral Awards is the principal legal act with international reach in this respect. Under this Convention, the judgements in both civil and commercial cases can be enforced, not only those in the territory of the country-signatory to the Convention. This is because the Convention commits the member states to recognise foreign arbitral awards as binding and to enforce them in accordance with the procedure in force in the state of enforcement. The document also stipulates explicitly the reasons for the refusal of enforcement, transferring the burden of proof to the party against whom the enforcement procedure in invoked.

Under the EU system, the principal legal act that regulates the jurisdiction, recognition and enforcement of judgements is Regulation (EU) no 1215/2012 of the European Parliament and of the Council of 12 December 2012 on jurisdiction and the recognition and enforcement of judgments in civil and commercial matters (known as Brussels bis), in force since 10.01.2015 [Official Journal of the European Union, L 351/1 of 20.12.2012]. The Regulation is applicable in both civil and commercial cases, regardless of the type of court involved. However, it does not cover the issues of relationships between common courts and arbitration 
bodies, and does not apply to arbitration cases, leaving these matters to other international law acts, including the New York Convention. Moreover, the discussed EU Regulation does not cover matters relating to tax, customs and administrative cases, nor the litigation concerning the liability of the State for actions or failure to act in exercising its statutory powers.

Under the 1215/2012 Regulation, an agreement conferring jurisdiction in international trade should be concluded in a form which accords with the usage of which the parties are aware, and which they regularly observe (Article 25, 1 (c)), while any communication by electronic means providing a durable record of the agreement is equivalent to a written form. Further, an agreement conferring jurisdiction, which forms part of the main contract, is treated as an agreement independent of other terms of the contract. Therefore, it is not possible to contest the validity of the agreement conferring jurisdiction solely on the grounds that the main contract is not valid.

If, regardless of their domicile, the parties have agreed that the courts of a member state should be competent to settle any disputes which have already arisen or which may arise, these courts should have jurisdiction, unless the agreement - under the law of that member state - is null and void as to its substantial validity. Such jurisdiction is treated as exclusive if the parties have not agreed otherwise. The court designated in the agreement conferring jurisdiction basically takes precedence over other competent courts, regardless of the court to which the case was originally brought. This limits the possibility of bringing cases to courts other than the court designated in the agreement.

If a case is being heard by a court in a third country, i.e. outside the EU territory, a competent court in a member state can suspend the proceedings, taking into account the proceedings pending before a third state's court, if there are justified reasons to expect that a judgement of the third State's court will be capable of being recognised and enforced in the member state in question.

Employees and consumers may sue the employers and entrepreneurs not domiciled in the EU before EU courts, regardless of these employers' or entrepreneurs' domicile or seat. In other cases, including those relating to international trade contracts, the possibility of a lawsuit depends on the defendant's being domiciled in the EU territory.

A judgment given in a member state should be recognised in other member states of the EU, even if it concerns a person not domiciled 
in a member state. When a judgement is given in a member state and enforceable in that member state, it should be enforceable in another member state without the need to establish its enforceability. Furthermore, such a judgment may not be reviewed as to its substance in the member state addressed, under any circumstances. A party invoking a judgment given in another member state must provide a copy of the judgment and an appropriate certificate. The court or other competent body before which such a judgment has been invoked may - if necessary - require it to be provided with a translation or a transliteration of the judgment.

In accordance with the procedure provided for in the Regulation, any interested party may apply for a decision that there are no grounds for refusal of a judgement recognition. Moreover, a judgement enforceable by operation of law constitutes the basis to apply any protective measures existing under the law of the member state addressed. Procedures related to the enforcement of judgements given in another member state should also be governed by the law of the member state addressed.

Recognition or enforcement may be refused on application of an interested party, if: a) recognition would be contrary to public order; b) the defendant was not served with the document which instituted the proceedings in sufficient time and in such a way as to enable him/her to arrange for his/her defence; c) the judgment conflicts with a judgment given in another member state or in a third State and involving the same cause of action between the same parties.

The Regulation does not affect the application of the Lugano Convention on Jurisdiction and the Enforcement of Judgments in Civil and Commercial Matters, which entered into force on 1 January 2010 and the aforementioned New York Convention of 1958.

\subsubsection{Commercial uses, customs and contractual clauses}

International trade is based to a large extent on commercial practice and usages. Commercial practice means a traditional way of proceeding when concluding a contract, or a widely accepted and uniform way of interpreting the terminology used in commercial exchanges. Its legal value, that is its role, place and scope of application - is defined by the domestic law applicable to a particular contract. It cannot be contradictory with the rules of the law in force: the parties to a contract enjoy the freedom of agreement on, and application of, customary commercial practices, 
yet still within the limits of the laws in force. Customary arrangements may only supplement the contractual provisions and must be explicit and widely known in commercial practice or in a particular business sector. Commercial usage is a trade practice officially recognised by a competent body and declared as binding or recommended.

The International Chamber of Commerce (ICC) in Paris is the principal organisation providing standardisation of various commercial practices. It has published a number of documents related to commercial practices used in international transactions settlements, namely: Uniform Customs and Practice for Documentary Credits (UCP 600), Uniform Customs and Practice for Documentary Credits for Electronic Presentation (eUCP), Uniform Rules for Collection (URC522), the Uniform Rules for Demand Guarantees (URDG458), Uniform Rules for Contract Guarantees (DOCDEX 811) and Documentary Instruments Dispute Resolution Expertise. In order to secure the precise definition and common interpretation of the terms and conditions of trade used in the contract, the ICC has published a number of subsequent versions of the International Commercial Terms (Incoterms), with the first version published as early as 1936, and the latest in 2010.They have brought together typical and most commonly used combinations of contractual commitments between buyers and sellers (in particular the costs and risks). When negotiating an international sales contract, the contractors should pay as much attention to the conditions and terms of trade as to the selling price.

The description of the subject of the contract should be precise enough to enable its clear identification, for example by a) indication of the trading name or brand of the good, supplemented by the necessary technical data, b) reference to a sample or a design (delivered before the conclusion of the contract and preserved for the purpose of claiming damages), c) a description with accompanying drawings, photographs, documentation and list of technical parameters, d) definition of the merchandise quality determined by the trading name, technical data accompanying the description of the subject of the contract or by appropriate merchandise standards.

The unit price of merchandise is expressed in the agreed currency of a contract with possible additional clauses (a valorisation clause or price review clause). The price remains closely related to a discount, a percentage reduction in price offered on purchase of a larger tranche of goods. A discount can be also offered to regular clients who refrain from buying competing products (customer discount/loyalty discount) or to 
the clients who - in a given period of time - purchased at least a predefined amount of goods (volume discount or quantity discount).

An early payment discount is a percentage discount that can be granted in the case of cash payment or payment made before the date agreed under the contract. In practice, this discount usually takes the form of an invoice rebate, written down in short on an invoice as e.g. 3/14 net. 30, meaning that for making a payment within 14 days, the buyer will receive a $3 \%$ discount and if the payment is made within 30 days, no interest on late payment will be charged.

A quality discount is offered to an importer, either on the exporter's initiative or as a result of a complaint accepted, if the goods delivered are of lower quality than stipulated in the contract. The specific names of these types of discounts evolved gradually in the case of goods subject to natural loss, such as: sticky substance adhering to the packaging - besemschon, drying up or shrinking down - decalo, liquid leaking out - leakage, or fusti, meaning the contamination of goods by foreign particles. Quality discounts and compensations are usually not included in the contract, although with regular partners and trade in homogenous goods, transported by the same means and to/from the same destinations, these discounts are provided for in the contract so as to avoid unnecessary costs and inconvenience connected with the discharge of the goods' quantity after their delivery.

The currency of the contract in which the price is expressed can be that of either of the parties or of a third country.

The quantity of goods is expressed in appropriate units of measurement (tonnes, metres, pieces, pairs, barrels). When the word 'circa' is added before the quantity of goods, it is commonly accepted that the variation amounts to $\pm 10 \%$, unless the parties have agreed otherwise.

The date/time of delivery, that is, the time of implementation of the contractual obligations, can be specified precisely as e.g. 25 October 2015 , or only approximately, subject to further clarification. The date of delivery can be expressed in a number of different ways. In transactions providing for instant delivery, the terms immediately, promptly or as soon as possible are used. However, as these terms are not very precise, they can be interpreted in a number of different ways. A delivery date may also mean a designated period within which the delivery of the goods should take place. In that case, the seller can deliver the goods on any day within the period, with customary notification of the forthcoming 
delivery required. The period can be specified by use of the following phrases: 'within a quarter ...', 'between ... (date) and ... (date)', 'within a month from ...', 'at the beginning of ... (month)', meaning between day 1 and 10, 'in the middle of ... (month)', meaning any day between $11^{\text {th }}$ and $20^{\text {th }}$ day of the month, 'at the end of ... (month)', meaning any day after the $16^{\text {th }}$, 'within a month' - between the first and last days of a month. Additionally, primo - means delivery within first 10 days of a month, medio - 10 middle days, and ultimo - last 10 days of a month. Some of the customs and standards have been borrowed from everyday language, for example a.s.a.p. (as soon as possible), which - in maritime transport - means the order to ship the goods by first vessel on which the entire consignment can be loaded, or as soon as the sea route is open. Similarly, immediately - means the order to ship by first accessible freight from a given port. The Loco formula means the sales of goods to be collected from the place where the goods were stored at the time of the conclusion of the contract, whereas the Franco formula means forwarding the goods to the recipient. These terms were commonly used before introduction of Incoterms.

Commercial formulas play an important role in defining the terms of delivery (also called delivery base or price formula) which specify whether the goods are to be made available to the buyer at the seller's own premises (group E), forwarded to a carrier or for loading to a means of transport (groups F and C), or delivered to a designated place (group D). As far as customs clearance is concerned, the last two versions of Incoterms provide for the rule that the exports customs clearance is executed by the exporter and the import customs clearance falls under the responsibility of the importer, with the exception of the EXW formula, where customs clearance in both exports and imports belong to the importer, and the DDP formula, where both are executed by the exporter. The seller, regardless of the commercial formula, is obliged to secure appropriate packaging (unless the contract provides otherwise), labelling and to provide evidence confirming that these obligations have been fulfilled. The buyer is obliged to accept - in the named place and at the time agreed - the properly individualised (labelled by the seller) merchandise as the subject of the contract, since from that moment the risk related to the goods passes on to him/her. As the Incoterms do not concern the shipping, banking or insurance arrangements, they do not apply to third parties - carrier, freight forwarder or insurer. An agreement on the use of certain Incoterms formulas contained in the trade contract 
may, however, cause implications for other contracts. If, for example, the CFR or CIF formulas are used, the seller cannot use other means of transport than by sea or inland waterways, because a bill of lading (not available in other means of transport) has to be submitted to the buyer. The type of required shipment document, required under the credit transaction, is also conditioned by the means of transport to be used. If, under the letter of credit arrangement, an AWB (Air waybill) is required, the seller may conclude a contract of carriage only with an air carrier.

The Incoterms do not determine issues related to change of ownership, liability waivers relating to unexpected incidents, nor about the consequences of contractual obligations infringements, except for the shift of responsibility in the case when the buyer has not fulfilled his obligation related to the acceptance of delivery or designation of a carrier (group F). The Incoterms require that the seller supply the goods conformant with the contract, but they do not deal with the consequences of the goods being not conformant with the contract. Therefore, in order to be complete and comprehensive, a contract needs to include individually negotiated provisions or standard commercial rules. Table 4.2 presents the division of costs between the seller and the buyer for each of 11 terms in Incoterms (version of 2010) 2010:

Division of the risk between the seller and the buyer under Incoterms

1. EXW $=$ EX Works (from the premises, $\ldots$ a named place) - all means of transport.

The seller's obligations related to delivery are fulfilled when the goods are made available at the seller's premises. The seller is not responsible for loading the goods on the vehicle provided by the buyer.

2. FCA $=$ Free Carrier (a named place) - all means of transport.

The seller is obliged to hand the goods over to the carrier (or other person, e.g. freight forwarder) named by the buyer. The costs of shipment, on its main route, are covered by the buyer, who takes over the risk at the moment when the goods have been handed over to the carrier. This formula provides for two options of delivery, depending on the place of handing the goods over to the charge of the carrier: 


\begin{tabular}{|c|c|c|c|c|c|c|c|c|c|c|c|c|c|c|}
\hline ดิ & 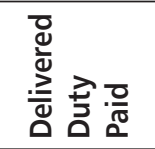 & $\frac{\bar{\varpi}}{\overline{\bar{\Xi}}}$ & $\frac{\bar{\Xi}}{\overline{\bar{d}}}$ & $\frac{\bar{\Phi}}{\overline{\bar{d}}}$ & $\frac{\bar{d}}{\bar{d}}$ & $\frac{\bar{\varpi}}{\overline{\bar{\varpi}}}$ & $\frac{\bar{d}}{\overline{\bar{\Phi}}}$ & $\frac{\bar{\Phi}}{\overline{\bar{d}}}$ & $\frac{\bar{\Phi}}{\overline{\bar{\Phi}}}$ & $\frac{\bar{\omega}}{\overline{\bar{d}}}$ & $\frac{\bar{d}}{\bar{\Phi}}$ & $\frac{\bar{d}}{\bar{\Phi}}$ & $\frac{\bar{\varpi}}{\overline{\bar{\varpi}}}$ & $\begin{array}{l}\text { vi } \\
\text { O } \\
\circ \\
0 \\
0 \\
0\end{array}$ \\
\hline 萦 & 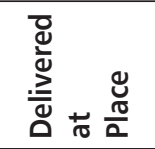 & $\frac{\bar{\varpi}}{\overline{\bar{\nu}}}$ & $\frac{\bar{\Phi}}{\overline{\bar{\nu}}}$ & $\frac{\bar{d}}{\overline{\bar{d}}}$ & $\frac{\bar{d}}{\bar{d}}$ & $\frac{\bar{\varpi}}{\bar{\Xi}}$ & $\frac{\bar{\Xi}}{\bar{\Xi}}$ & $\frac{\bar{\Phi}}{\overline{\bar{\Xi}}}$ & $\frac{\bar{\Phi}}{\overline{\bar{\Xi}}}$ & $\frac{\bar{\varpi}}{\overline{\bar{d}}}$ & $\sum_{\bar{\infty}}^{\bar{D}}$ & $\grave{\infty}_{\bar{\emptyset}}^{\bar{\Phi}}$ & $\frac{\bar{d}}{\bar{\Phi}}$ & $\begin{array}{l}\text { 이 } \\
\frac{1}{0} \\
\text { 으 }\end{array}$ \\
\hline 造 & 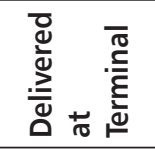 & $\frac{\bar{\varpi}}{\overline{\bar{\nu}}}$ & $\frac{\bar{\Phi}}{\overline{\bar{\Phi}}}$ & $\frac{\bar{\Phi}}{\overline{\bar{\Xi}}}$ & $\frac{\bar{d}}{\bar{\Xi}}$ & $\frac{\bar{\varpi}}{\overline{\bar{\varpi}}}$ & $\frac{\bar{亠}}{\overline{\bar{\Xi}}}$ & $\frac{\bar{\Phi}}{\overline{\bar{\Xi}}}$ & $\frac{\bar{\Phi}}{\overline{\bar{\Xi}}}$ & $\frac{\bar{\varpi}}{\overline{\bar{d}}}$ & $\frac{\bar{\varpi}}{\overline{\bar{\nu}}}$ & 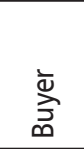 & 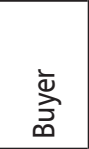 & 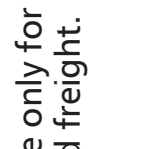 \\
\hline 은 & 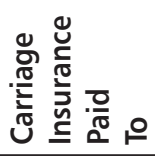 & $\frac{\bar{\varpi}}{\bar{\Xi}}$ & $\frac{\bar{\varpi}}{\bar{\Phi}}$ & $\frac{\bar{d}}{\bar{\Phi}}$ & $\frac{\bar{d}}{\bar{d}}$ & $\frac{\bar{\varpi}}{\bar{\varpi}}$ & $\frac{\bar{d}}{\bar{\Xi}}$ & $\frac{\bar{\Phi}}{\overline{\bar{\Xi}}}$ & $\frac{\bar{\Phi}}{\overline{\bar{\Xi}}}$ & $\frac{\bar{d}}{\overline{\bar{d}}}$ & $\frac{\bar{d}}{\bar{\Phi}}$ & 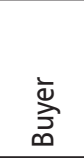 & $\overbrace{\bar{\infty}}^{\bar{\Delta}}$ & 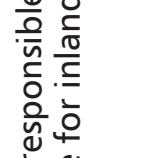 \\
\hline ᄂ & 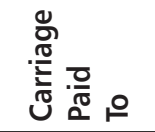 & $\frac{\bar{\varpi}}{\overline{\bar{\nu}}}$ & $\frac{\bar{\varpi}}{\bar{\Xi}}$ & $\frac{\bar{\Phi}}{\bar{\Xi}}$ & $\frac{\bar{d}}{\bar{\Phi}}$ & $\frac{\bar{\varpi}}{\bar{\Xi}}$ & $\frac{\bar{\varpi}}{\bar{\Xi}}$ & $\frac{\bar{亠}}{\bar{\Xi}}$ & $\frac{\bar{\Phi}}{\bar{\Xi}}$ & $\frac{\bar{\varpi}}{\overline{\bar{d}}}$ & $\frac{\bar{\varpi}}{\bar{\varpi}}$ & $\grave{\infty}_{\bar{\infty}}^{\bar{\nu}}$ & 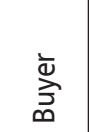 & 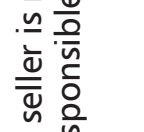 \\
\hline 岂 & 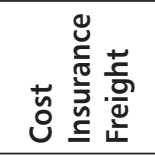 & $\frac{\bar{d}}{\overline{\bar{\Xi}}}$ & $\frac{\bar{\Phi}}{\overline{\bar{\Xi}}}$ & $\frac{\bar{\Phi}}{\overline{\bar{\Xi}}}$ & $\frac{\bar{d}}{\overline{\bar{d}}}$ & $\frac{\bar{\varpi}}{\overline{\bar{\varpi}}}$ & $\frac{\bar{亠}}{\overline{\bar{\Xi}}}$ & $\frac{\bar{\Phi}}{\overline{\bar{\Xi}}}$ & $\frac{\bar{\Phi}}{\overline{\bar{\Xi}}}$ & $\frac{\bar{\omega}}{\overline{\bar{d}}}$ & 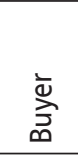 & 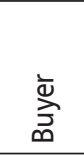 & 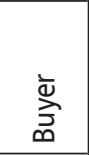 & 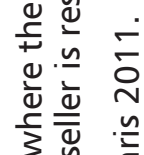 \\
\hline 営 & 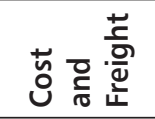 & $\frac{\bar{d}}{\bar{\varpi}}$ & $\frac{\bar{\Phi}}{\overline{\bar{\Xi}}}$ & $\frac{\bar{\Phi}}{\overline{\bar{\Xi}}}$ & $\frac{\bar{d}}{\overline{\bar{d}}}$ & $\frac{\bar{\varpi}}{\bar{\Xi}}$ & $\frac{\bar{d}}{\overline{\bar{d}}}$ & $\frac{\bar{\Phi}}{\overline{\bar{\Xi}}}$ & $\frac{\bar{\Phi}}{\overline{\bar{\Xi}}}$ & $\frac{\bar{\varpi}}{\overline{\bar{d}}}$ & $\grave{D}_{\bar{\infty}}^{\bar{\nu}}$ & $\varlimsup_{\bar{\emptyset}}^{\bar{\nu}}$ & \্ळ & 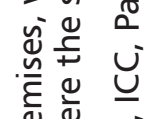 \\
\hline 운 & 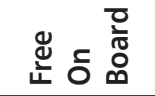 & $\frac{\overline{\bar{\Xi}}}{\bar{\Xi}}$ & $\frac{\bar{\varpi}}{\overline{\bar{\varpi}}}$ & $\frac{\bar{\Phi}}{\bar{\Phi}}$ & $\frac{\bar{d}}{\bar{\Xi}}$ & $\frac{\bar{\varpi}}{\overline{\bar{\varpi}}}$ & $\frac{\bar{亠}}{\bar{\Xi}}$ & $\stackrel{\bar{\varpi}}{\grave{\infty}}$ & $\frac{\bar{\Phi}}{\overline{\bar{\Xi}}}$ & 产 & $\grave{\infty}_{\bar{\infty}}^{\bar{亠}}$ & $\grave{\infty}_{\bar{\infty}}^{\bar{\nu}}$ & $\overbrace{\bar{\infty}}^{\bar{\nu}}$ & 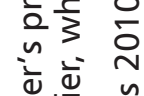 \\
\hline$\frac{n}{4}$ & 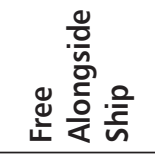 & $\frac{\bar{d}}{\overline{\bar{d}}}$ & $\frac{\bar{d}}{\bar{\Phi}}$ & $\frac{\bar{d}}{\bar{\Phi}}$ & $\begin{array}{l}\frac{\bar{d}}{\bar{d}} \\
\sim\end{array}$ & $\frac{\grave{d}}{\overline{\bar{d}}}$ & $\frac{\bar{d}}{\overline{\bar{d}}}$ & ‡্̀ & 产 & \begin{tabular}{|l|}
$\grave{D}$ \\
$\grave{\Delta}$ \\
\end{tabular} & 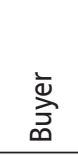 & 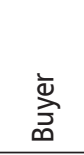 & $\overbrace{\bar{\infty}}^{\bar{D}}$ & 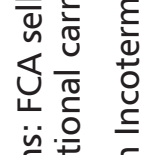 \\
\hline త্ড & 这 & $\stackrel{\bar{\varpi}}{\overline{\bar{\sigma}}}$ & $\frac{\bar{d}}{\bar{\Phi}}$ & $\frac{\bar{d}}{\bar{\Phi}}$ & $\begin{array}{l}\frac{\bar{d}}{\bar{d}} \\
\sim\end{array}$ & 离 & $\overbrace{\bar{\infty}}^{\bar{亠}}$ & $\grave{D}_{\bar{\infty}}^{\bar{D}}$ & 产 & 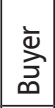 & $\grave{D}_{\bar{\infty}}^{\bar{\nu}}$ & $\overbrace{\bar{\emptyset}}^{\bar{\nu}}$ & $\widehat{D}_{\bar{\infty}}^{\bar{\nu}}$ & 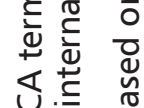 \\
\hline 文 & × & $\frac{\bar{d}}{\bar{\varpi}}$ & $\frac{\bar{\Xi}}{\overline{\bar{\nu}}}$ & $\frac{\bar{d}}{\overline{\bar{d}}}$ & 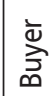 & $\stackrel{\bar{\emptyset}}{\grave{\infty}}$ & 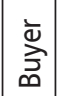 & 㐫 & 㐫 & \begin{tabular}{|c|}
$\bar{\Phi}$ \\
$\grave{\infty}$ \\
$\bar{\infty}$
\end{tabular} & \} $&{\grave{\infty}_{\bar{\emptyset}}^{\bar{\varpi}}} &{\text { 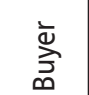 }} &{\text { 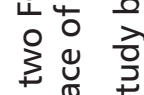 }} \\
{\hline} &{\text { 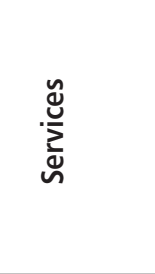 }} &{\text { 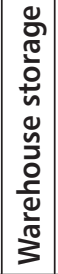 }} &{\text { 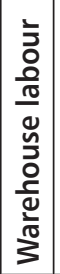 }} &{\text { 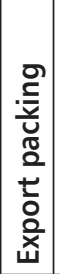 }} &{\text { 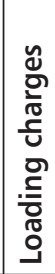 }} &{\text { 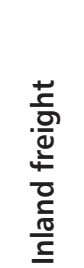 }} &{\text { 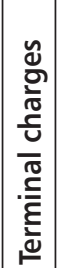 }} &{\text { 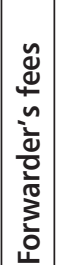 }} &{\text { 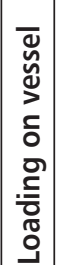 }} &{\text { 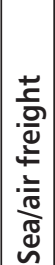 }} &{\text { 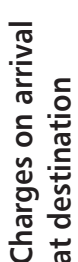 }} &{\text { 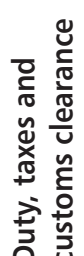 }} &{\text { 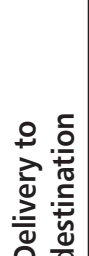 }} &{\text { 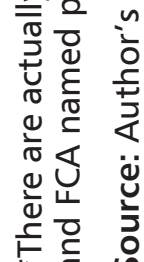 }} \\
$\hline
\end{tabular}


1) if the delivery takes place on the premises of the seller, it is regarded as being effected when the goods have been loaded on the means of transport provided by the carrier,

2 ) if the place is different from the seller's premises or warehouse (e.g. depot, port), the delivery is deemed to have been effected after handing the goods over to the carrier on the means of transport provided by the seller. The unloading of the goods from the seller's means of transport does not fall under the seller's responsibility. If the place of handing the goods, the carrier or the time of delivery have not been specified by the buyer, or if the carrier has not accepted the goods for any reason, the entire risk for the goods loss of damage passes on to the buyer, on condition that these goods have been appropriately identified as the subject of the contract.

3. FAS $=$ Free Alongside Ship (a named port of loading) - transport by sea or inland waterways.

The seller's obligations are fulfilled when the goods have been placed alongside a vessel in a quay at the designated port of loading. The seller is responsible for the exports customs clearance and remittance of the cost related thereof.

4. $\mathrm{FOB}=$ Free On Board (a named port of loading) - transport by sea or inland waterways.

The seller is responsible for delivery of goods to the carrier named by the buyer. The costs of delivery along the main route are not paid by the seller. The risk of loss or damage is transferred to the buyer when the goods have passed the ship's rail in the port of loading. The seller is responsible for the customs clearance of the goods in exports, while the buyer undertakes all costs of remaining risks related to transportation from the moment the goods are placed on board the ship.

5. $\mathrm{CFR}=$ Cost and Freight (a named port of destination) - transport by sea or inland waterways; for combined transport, CPT Incoterms are recommended.

The organisation of transport (concluding the contract of carriage) and related costs belong to the seller. The seller is also obliged to 
deliver the goods to the carrier, or if there are several of them, to the first carrier in line. From that moment, the risk related to damage is transferred to the buyer. If the buyer wishes to indemnify the goods, the seller is obliged to provide all information necessary to conclude an insurance contract.

6. $\mathrm{CIF}=$ Cost, Insurance and Freight (a named port of destination) - transport by sea or inland waterways exclusively; for combined transport, CPT Incoterms are recommended.

Under this arrangement, the scope of responsibilities, division of costs and risk is analogous to that under CFR, with further responsibility for concluding the insurance contract and payment of its costs added. The seller must provide the buyer with evidence concerning the insurance of the goods so that the buyer can claim damages from the insurer. The risk of loss or damage is transferred from the seller to the buyer at the moment the goods have passed the ship's rail.

7. CPT = Carriage Paid To (a named place of destination) - all means of transport, including combined transport.

The seller is responsible for concluding the contract of carriage to the designated point of delivery and to pay the costs of shipment. $\mathrm{He} / \mathrm{she}$ is also obliged to deliver the goods to the carrier, or - if there are several carriers involved - to the first of them. From that moment, the risk of the goods' loss or damage is transferred to the buyer. The seller's responsibility is also the clearance of goods in exports.

8. CIP = Carriage and Insurance Paid To (a named place of destination) - all means of transport, including combined transport.

Compared to that under the CPT formula, the scope of the seller's responsibility is extended to the obligation to conclude the insurance contract and to pay its costs.

9. DAP = Delivered at Place (a named place of destination) - all means of transport.

The seller's obligations are fulfilled when the goods are delivered at the place designated by the buyer. The risks and costs related to delivery, with the exclusion of customs duties, taxes and other charges 
due in the buyer's country, are incurred by the seller. The buyer bears the costs of import customs clearance.

10. DAT $=$ Delivered at Terminal (a named place) - all means of transport.

The seller's delivery obligations are fulfilled when the goods are delivered and unloaded in the depot. The risk and costs of unloading are borne on the side of the seller, while the costs of import custom clearance are on the side of the buyer.

11. DDP $=$ Delivered Duty Paid (a named place of destination) - all means of transport.

The seller's obligations are fulfilled when the goods have been delivered to the place indicated by the buyer. All costs and risks, except for the import customs duties in the country of the buyer, are incurred by the seller. Thus, the seller assumes the largest responsibility, unlike under the EXW formula.

\subsubsection{Additional contract clauses}

Conditions and terms of inspection and receipt of goods. The aim of an inspection is to establish the current status of the contract implementation, while the receipt of the goods makes it possible to check their conformity with the contractual provisions. The check may be performed on one's own, usually by the supplier, or it may take the form of a contracted control, where the procedures are performed by competent organisations. It is also possible that the inspection takes place ex officio, and is carried out by state authorities. The costs related to the inspection, depending on the contractual provisions, are incurred by either the seller or the buyer. Where and how the goods are received are negotiated and later specified in the contract.

A contract validity clause suspends the contract's entry into force until the conditions agreed upon in the contract are met or required documents are delivered, e.g. This contract shall enter into force on condition that the exports licence is obtained by the exporter or The contract shall enter into force provided that the opening of the letter of credit shall take place not later than two weeks after the conclusion of the contract. 
A governing law/law applicable clause, indicates the law to which the parties, judges or arbitrators refer in case of disputes or conflicts between the parties.

Force majeure and hardship clauses are incorporated into the contract in order to protect the parties from events that obstruct or completely exclude the fulfilment of the contractual obligations. Such a clause allows relief from the responsibility for non-performance of the contract by the party affected by circumstances agreed upon in the contract. This clause should contain a list of such conditions, e.g. flooding, industrial action, outbreak of war, revolution, riots, etc. The notion of Act of God can also be understood in a wider context and may cover the following: shortages in supplies, transport difficulties and other events hindering the performance of a contract.

Act of God and hardship. An Act of God is defined as sudden events against which the parties cannot protect themselves and which hamper or exclude the possibility of fulfilling the undertaken obligations. Act of God circumstances are those which arise after the conclusion of the contract and occurring due to irreversible and extraordinary incidents, unforeseen by the parties. The hardship clause can be referred to as a provision that the contract is in force as long as the relations existing between the parties at the time of the contract conclusion are not fundamentally altered. Such a change of circumstances very often results from force majeure occurrence. However, the aim of rebus sic stantibus (Latin for things thus standing) clauses is usually not to relieve or lessen the contractual obligation of the parties, but to undertake actions leading to changes in the contract and renegotiation of the price. Therefore, in commercial practice, the Act of God clauses need to be invoked more often than the hardship clauses.

An arbitration clause may appoint arbitration as the way disputes resulting from performance of the contract. These disputes may be heard by either common courts or arbitration tribunals. Due to the high costs of proceedings before common courts, complicated procedures and the number of instances involved, in trading practice the disputes are usually brought before arbitration courts. Compared to common courts' procedures, arbitration has numerous advantages: the disputes are heard by experts, which is not always the case in common courts, the case is resolved in a relatively short period of time and usually by one instance only. Additionally, the arbitration costs are lower compared to those of court cases, and legal substitution (counsel for the defence) is not required. 
A liquidated damage clause. In international practice, it is widely accepted that the amount of the penalty should correspond to the amount of actual damage which the parties could reasonably foresee while drawing up the contract. In a case when liquidated damages are provided for in the contract, and in the absence of other provisions, the party injured cannot claim from the debtor a compensation exceeding the penalty restricted under the contract, even if the actual damages are higher. The liquidated damage, under certain circumstances, may be subject to moderation (if the main essential commitment has been performed for the most part or when the amount of penalty is excessive).

A valorisation clause consists in fixing the payment under the contract to the currency subject to relatively low exchange rate fluctuations. Such a clause protects the parties against exchange rate risk. We can name five forms of currency clause:

- full - when the exchange rate of the contract currency changes, the price or the invoice value changes proportionally on the day of payment;

- rate of exchange based - the contract value is compared with the exchange rate of another, 'strong' currency (e.g. USD) on the date of the contract conclusion; a ratio fixed in this way remains unchanged and constitutes the basis for further calculations, resulting from the exchange rates on the date of payment;

- currency basket based - the currency of the contract is compared with the currency basket formed by the currencies chosen by the parties;

- automatic price adjustment in (full or in a certain) proportion of the fluctuations in the exchange rate of the contract currency to the domestic one - the clause comes into operation when the exchange rate fluctuations of the payment currency exceed the agreed percentage index e.g. $\pm 4 \%$;

- the price revision clause contains the provision that, in the case of a specified depreciation of the contract currency against strong currencies (e.g. over 5\%), the exporter reserves the right to change the export price, i.e. a renegotiation of the price may take place. 
A complaint clause - specifies 1) the times and modes for making complaints relating to both quantity and quality (e.g. a restriction that a claim should be submitted in writing); 2) the methods of documenting the claims so that the possibility to obtain additional benefits at the expense of the partner is excluded; 3) legitimacy of the claim and covering of the costs related thereof; 4) the way of dealing with the claim (repair, price reduction, etc.); 5) the way of preserving defective or faulty goods for evidence; 6 ) other necessary actions to be undertaken under the procedure, according to the nature of the claim or the specificity of the goods. Failure to submit a claim in the time specified deprives the claimant of the ability to claim damages under arbitration procedures.

It is advisable to incorporate into the contract other clauses adequate to the specificity of the transactions in certain goods or relating to the market situation. These can be:

- a warranty clause, which specifies the details of the warranty granted by the seller to the importer and to final buyers;

- a clause defining the conditions of the receipt of goods, i.e. required certificates, or the results of test or checks which must be performed prior to the receipt of goods;

- a clause on the integrity of the trademark, brand or design.

\subsection{Settlement of international business transactions}

Payments in international trade may be divided into two basic categories:

1. Unconditional - the beneficiary does not have to fulfil any additional conditions to receive the payment for the goods or services rendered (payment order, cheque, draft).

2. Conditional - to receive the payment, the beneficiary needs to fulfil specified conditions, most often by submitting appropriate documents representing the merchandise and relating to the obligations put on the buyer (documentary encashment and documentary letter of credit). 
A payment order constitutes the least costly, fastest and easiest form of settlement in international trade. It consists in an instruction to make a payment received from or addressed to a bank, referring to the disbursement of a given sum for the benefit of the designated beneficiary.

A cheque is a document issued on a special form, bearing the unconditional order for disbursement by the bank - from the issuer's account - of the sum specified to the bearer of the cheque or the person named on the cheque. The issuer of the cheque is called the 'drawer', the bank is the 'drawee' and the person receiving payment is referred to as 'payee'.

In international transaction, banker's cheques are in use most often, made out by one bank to another bank or to a natural or legal person. It opens the possibility of receiving the payment directly after its submission to the bank.

A draft, like a cheque, is a security with the form specified by the bill of exchange laws. There are two kinds of drafts:

- a Bill of Exchange (drawn), also called a draft, issued by the exporter, who orders the buyer or his bank to pay the specified amount;

- a Promissory note, made by the importer in exchange for the goods received.

In documentary collection, the importer undertakes to settle the payment for the goods in exchange for the documents representing them. The exporter sends the documents, together with the collection instruction, directly or (more often) via his/her bank (intermediary bank) to the importer's bank (collecting bank), which in turn summons the importer to buy out the documents. Documentary collection does not offer sufficient certainty to the exporter, because the importer may refuse to buy out the documents submitted by the encashing bank.

A letter of credit (L/C) - the document by which the bank opening the credit authorises another bank to pay a determined sum to the payee named in the $L / C$ and at the time fixed in the document. Under the L/C, the intermediary bank (the exporter's bank) is not involved at all: the opening bank sends the letter of credit directly to the beneficiary. The content of the letter authorises the beneficiary to make drafts drawn by $\mathrm{him} / \mathrm{her}$. 
A documentary credit $(D / C)$ constitutes an obligation of the bank, undertaken on the order of the importer, to pay to the beneficiary a fixed amount in exchange for the submission of documents - within the time specified - indicated in the credit document. The trade contract specifies the types of documents that the exporter will have to submit under the agreed credit arrangement. They are later reproduced by the importer in the order for the opening of the credit addressed to the bank and in the contents of the bank documents related to the credit opened. Banks usually provide standard forms to be filled in by the importer. Depending on the role of the opening bank (the importer's bank), letters of credit can be divided into revocable and irrevocable. In the case of revocable credit, the conditions may be altered without notifying the exporter. From the point of view of the risk it carries, this type of credit arrangement is close to encashment. Irrevocable credit cannot be cancelled or any of its conditions altered without prior approval by all parties involved. This type of credit fully secures the interests of the beneficiary.

From the point of view of the intermediary bank (the exporter's bank), (letters of) credit arrangements can be divided into confirmed, unconfirmed, advised and in the form of a letter of credit. In the case of a confirmed credit arrangement, the intermediary bank undertakes an identical commitment to the beneficiary (exporter) as the opening bank and takes on the obligation to pay the fixed amount to the exporter. The confirmation takes place on the order of the opening bank, while the intermediary bank has the right to refuse confirmation.

An unconfirmed credit arrangement can be of the nature of either an advised credit or a negotiation credit. In a negotiation credit, the intermediary bank has the right to negotiate the documents submitted by the beneficiary, that is, to check their compliance with the credit conditions. In the case of an advised credit arrangement, the role of the intermediary bank is limited to notifying the exporter about the opening of the credit, the subsequent forwarding of its contents and later to the receipt of the documents and their transferral to the opening bank.

In the case of a transferable credit arrangement, the beneficiary (exporter) has the right to order his/her bank (authorised to make the payment or negotiating the documents) to make a one-time transfer of the credit value, in full or in part, to the benefit of a third party. The partner opening the credit must give his/her permission for the credit to be transferrable. A revolving documentary credit constitutes the type in which the total amount, covering the value of the entire contract (the 
limit or ceiling), is fixed. This amount can be used by the beneficiary in parts, with each part covering the value of a single delivery, thus gradually reducing the total credit value.

The arrangement providing for back-to-back D/C authorises the intermediary bank to open - against one D/C - another one for the benefit of another beneficiary, so that the transfers from the original one would cover withdrawals from the second.

When formulating a contract, one should pay particular attention to the following and check if the contract: includes a detailed description of the goods, price and terms of delivery; specifies the procedures for dispute resolution and the law governing the contract; provides the reasons for withdrawal from the entire contract or from part; gives the time of delivery; contains precise payment terms and guarantees. Frequent formal mistakes in international contracts are as follows: the contract is signed by a partner's representative without proper plenipotentiary powers; the stamp bears invalid data; the absence of dates, official names of the parties and clear ending with the parties' signatures; the absence of definitions for terms whose meaning may cause doubts; the use of terms which meaning may be different in various languages; the quality or condition of goods is not sufficiently specified; the absence of permitted tolerances regarding the weight, volume or other quantitative or qualitative features which can be subject to change during the fulfilment of the contract; the absence of penalties for late payments; the absence of payment guarantees; unclear provisions as to the time and place of the transfer of the ownership and the risk to the recipient; the choice of the third country law as the law governing the contract, which can result in high legal costs; the choice of arbitration court in the arbitration clause whose impartiality is doubtful; the lack of a force majeure clause and other clear reasons for the exclusion of parties' responsibility in exceptional situations; the absence of a revaluation clause in the situation of considerable exchange rate fluctuations; the adoption of unrealistic or risky dates of delivery; the absence or unclear formulation of clauses relating to the rules of inspection and the receipt of goods; inaccurate description of the subject of the contract, without type, brand, kind, size or quality.

\section{Questions and assignments}

1. Explain which of the settlement forms in international trade is most advantageous for the exporter and which for the importer. 
2. Where risks and costs are transferred from the seller to the buyer in a contract based on CIF?

3. What law governs a contract concluded between an EU exporter and an Argentinian importer?

4. How it is possible to diminish or eliminate exchange rate risk in international transactions?

5. What are the benefits for the parties resulting from the introduction of the force majeure clause into a contract?

6. Explain the reasons for forming strategic alliances in international trade.

7. Describe types of intermediaries and their roles in international trade.

8. Describe offset transactions and their advantages for the parties involved.

9. Describe the international commercial transactions which allow the problems resulting from the absence of convertible currencies to be minimised.

\section{Literature}

Brand R.A (2000), Fundamentals of International Business Transactions, Kluwer Law International, N.Y.

Cateora P.R., Graham J.L. (2007), International Marketing, McGraw-Hill/Irwin, N.Y.

Cavusgil T., Knight G., Riesenberger J. (2007), International Business. Strategy, Management \& the New Realities, Prentice Hall, N.Y.

Chow D.C.K, Schoenbaum T.J. (2010), International Business Transactions. Problems, Cases and Materials, Aspen Publications, N.Y.

Cook T. A., Alston R. K. (2012), Mastering Import \& Export Management, second edition, AMACOM, Berkshire.

Duliniec E. (2004), Marketing międzynarodowy, PWE, Warszawa.

Fonfara K., Ciesielski M. (1999), Biznes międzynarodowy, Poznańska Drukarnia Naukowa, Poznań.

Gorynia M. (2000), Podstawy strategii przedsiębiorstw w biznesie międzynarodowym [in:] Strategie przedsiębiorstw $w$ biznesie międzynarodowym, ed. M. Gorynia, Wydawnictwo Akademii Ekonomicznej w Poznaniu, Poznań. 
Stępień B. (ed.) (2007), Handel zagraniczny, PWE, Warszawa.

ICC Uniform Customs and Practice for Documentary Credits, "Publication" no. 600 ICC, Paris 2006.

INCOTERMS 2010, (2011), ICC, Paris.

Johnson Thomas E., Bade Donna L. (2010), Export/Import Procedures and Documentation, Fourth Edition, AMACOM, Berkshire.

Marciniak-Neider D. (2011), Rozliczenia międzynarodowe, PWE, Warszawa.

Nelson C. (2009), Import/Export: How to Take Your Business Across Borders, McGraw-Hill Education, Berkshire.

Oded S., Yadong L., Tailan C. (2015), International Business, Third Edition, Routledge, Taylor \& Francis Group, London.

Podstawy handlu zagranicznego, (2010), Difin, Warszawa.

Ram S. (2009), International Trade Operations, Excel Books, 2009. New Delhi.

Rymarczyk J. (2005), Handel zagraniczny, PWE, Warszawa.

Somraj K. (2014), An Introduction to International Trade, Shroff Publishers \& Distributors Pvt. Ltd. Mumbai.

Sherlock J., Reuvid J. (2011), International Trade: An Essential Guide to the Principles and Practice of Export, Kogan Page Limited, London.

Tubielewicz A. (2004), Zarządzanie strategiczne w biznesie międzynarodowym; Wydawnictwo Naukowo-Techniczne, Warszawa. 
Running a business on an international scale requires not only a substantial body of knowledge but also the ability to apply it in practice. That is why our textbook, with a vast collection of practical examples, discusses a wide variety of pertinent issues connected with business operations in international markets, from international market analysis, drafting business plans, concluding business transactions and the insurance of goods through to customs clearance procedures and professional etiquette. We also explain the specificity of doing business online.

The book is addressed primarily to students of courses in economics and management. We hope it will also make interesting reading for entrepreneurs and people indirectly involved in international business, who work in its immediate environment in banks, chambers of commerce and consulting companies and those who have dealings with public administration at different levels in foreign countries.
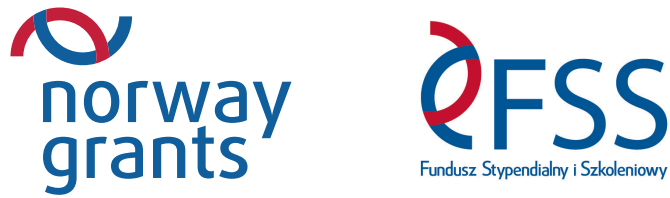

Project: The creation of new interdisciplinary curricula in the field of economics of environmental protection (in Polish and English) at the University of Łódź. Project supported by a grant from Norway through the Norway Grants and co-financed by the Polish funds.

The aim of the project is to improve the knowledge and awareness of Polish and foreign students, the faculty and alumni of the University of Łódź in the fields of sustainable development, ecology, international business and finance.

Grant amount: 533083 PLN

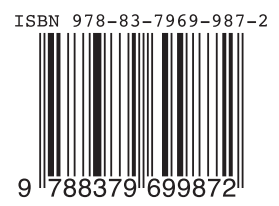

